\title{
Standard of Protection of Farm Animals in a Selected Region of the Czech Republic
}

\author{
V. VEČEREK ${ }^{1}$, V. PIŠTĚKOVÁ ${ }^{1}$, J. DOUSEK$^{2}$, P. CHLOUPEK ${ }^{1}$ \\ ${ }^{1}$ Department of Veterinary Public Health and Forensic Medicine, Faculty of Veterinary Hygiene and Ecology, \\ University of Veterinary and Pharmaceutical Sciences, Brno, Czech Republic, \\ ${ }^{2}$ State Veterinary Administration of the Czech Republic, Prague, Czech Republic
}

\author{
Received January 11, 2002
}

Accepted June 19, 2002

\section{Abstract}

Večerek V., V. Pištěková, J. Dousek, P. Chloupek: Standard of Protection of Farm Animals in a Selected Region of the Czech Republic. Acta Vet. Brno 2002, 71: 263-268.

The objective of the work was to evaluate the standard of protection of cattle, sheep and goats, pigs and horses against cruelty in 14 districts of the South Moravian Region in the Czech Republic in the period from 1996 to 2000. During the supervision of the animal - rearing units, the standard of protection of animals against maltreatment was evaluated by the following scale: no veterinary or legal problem, veterinary measures of varying extent needed to improve the welfare of animals (veterinary measures), and infringement of the requirements for the protection of animals against maltreatment with subsequent recourse for such maltreatment (non-fulfilment of requirements). The frequency of veterinary measures and the frequency of non-fulfilment of the requirements were checked in the individual districts of the monitored region. The frequencies found were compared with the long-term values obtained within the Czech Republic as a whole (veterinary measures and non-fulfilment of requirements for cattle $2.5 \%, 1.3 \%$; for sheep and goats $9.7 \%, 5.5 \%$; for pigs $1.6 \%, 0.7 \%$; for horses $4.4 \%, 1.9 \%$ ). Statistically, considerably worse conditions for animals on farms were found: for cattle in the Districts of Kroměříž (veterinary measures $p<0.01$; non-fulfilment of requirements $p<005$ ) and Zlín (veterinary measures $p<0.01$; non-fulfilment of requirements $p<0.05$ ), for pigs in the Districts of Kroměříž (veterinary measures $p<0.01$; non-fulfilment of requirements $p<0.01$ ) and Uherské Hradiště (veterinary measures $p<0.05$; non-fulfilment of requirements $p<0.01$ ), and for horses in the District of Ždár nad Sázavou (veterinary measures $p<0.01$; non-fulfilment of requirements $p<0.01$ ). Farmers in these districts of the South Moravia Region do not assure sufficiently the conditions for animal protection.

Protection of animals, cattle, pigs, horses, veterinary measures, non-fulfilment of requirements.

The standard of protection of farm animals is specified by legal regulations valid in every country. They specify conditions preventing the most striking forms of maltreatment, suffering and hardship of animals. Implementation of these legal requirements for the protection of animals is in the power of relevant institutions. Under the same legal regulations the standard of animal protection can, however, vary in the individual regions. The present study compares the standard of protection of several farm animal species in selected region with unified legal regulations with the long-term values for the Czech Republic as a whole.

Setting the conditions that influence animals' lives so as to protect them was dealt with in particular by Broom (1991a, 1991b, 1996), Sambraus (1992, 1997), Rushen (1996), Steinhardt and Thielscher (1998), von Borell (1999), Meyer (2000), and Ruizde-la-Torre et al. (2001), Broom and Corke (2002).

The basic requirements for conditions corresponding to the standard of knowledge of the protection of farm animals are contained in the relevant legal regulations. In the Czech Republic, these regulations are mostly contained in the Act for the Protection of Animals against Cruelty and the bylaws about the slaughter of animals. In the European Union, the

Address for correspondence:

Doc. MVDr. Vladimír Veãerek, CSc.,

Sciences Brno

Palackého 1-3, 61242 Brno, Czech Republic
Phone: +420541562614

Fax: +420 549243020

http://www.vfu.cz/acta-vet/actavet.htm 
requirements for the protection of farm animals are contained in the relevant EU guidelines.

The protection of animals kept for economic purposes is supervised in the Czech Republic by District Veterinary Administration offices and in some cases the State Veterinary Administration, which meet the requirements for competent authorities in accordance with the European Union's regulations.

Since 1993, an intensive system of monitoring and evaluating the protection of farm animals has been carried out in the Czech Republic. In the literature available, no other system of monitoring the protection of farm animals as comprehensive as this one has been recorded. The aim of this study was to monitor how the requirements for the protection of certain animals are fulfilled in relation to the legislative requirements for the protection of animals. Studies dealing with pigs and transportation of animals were described by Horváth and Visnyei (2000, 2001).

\section{Materials and Methods}

In the period from 1996 to 2000, the standard of protection of cattle, sheep and goats, pigs, and horses was monitored in a selected region of the Czech Republic. The monitored region included 14 districts of the South Moravia Region, specifically the Districts of Jihlava, Ždár nad Sázavou, Blansko, Prostějov, Kroměříz, Zlín, Uherské Hradiště, Hodonín, Břeclav, Brno-District, Brno-City, Třebíč, Znojmo, and Vyškov. This region was selected for its agricultural traditions and sufficient representation of all selected farm animal species. Veterinary inspectors of animal protection supervised the protection of the animals in the places of rearing. The results of each supervisory activity were recorded in a report. Each supervisory activity was evaluated by the following scale: requirements fulfilled, veterinary measures of certain extent needed to improve the welfare of animals (veterinary measures), and infringement of the requirements for the protection of animals against maltreatment with subsequent recourse for such maltreatment (non-fulfilment of requirements). Veterinary measures, a variety of veterinary treatments were taken in the event that the requirements for the protection of animals against maltreatment were not infringed, but the rearing standard and the treatment of animals did not result in good enough welfare in the animals; the measures included particularly treatment of animals, feed, water, waste, zoo-hygienic measures, and measures to prevent animals from being infected. The non-fulfilment of requirements was represented by infringement of the requirements for animal protection against maltreatment. Particular requirements which were not fulfilled were: sufficient feeding and watering of animals, treatment of animals which prevented or reduced pain, suffering and damage to the animals' health, and also inappropriate technologies of breeding, zoo-hygienic conditions evoking a stress in animals, and requirements including a ban or reduction of painful operations on animals, and possible killing of animals without reason. Such non-fulfilment of the requirements for animal protection was solved by imposing a remedy to eliminate the inappropriate treatment, or a penalty was imposed on those who infringed the requirements for animal protection. The frequency of veterinary measures and the frequency of non-fulfilment of the requirements for the protection of the selected kinds of farm animals against maltreatment were checked in the individual districts of the monitored region. The frequencies found were compared to the long-term values obtained within the Czech Republic as a whole. The results were statistically processed by a $\chi^{2}$ test using the Unistat 5.0 software.

\section{Results}

Concerning cattle, the results of the actual frequency of veterinary measures and the frequency of non-fulfilment of the requirements for protection against maltreatment for the monitored period in the individual districts of the monitored region and within the Czech Republic are stated in Table 1. Table 2 contains the relative frequency of veterinary measures and the frequency of non-fulfilment of the requirements for the protection of cattle against maltreatment for the monitored period in the individual districts of the monitored region. These are compared with the $2.5 \%$ relative frequency of veterinary measures and the $1.3 \%$ relative frequency of non-fulfilment of requirements found over the long term within the Czech Republic as a whole. The results show that both higher values of the frequency of veterinary measures and higher values of the frequency of non-fulfilment of requirements were found in the Districts of Ždár nad Sázavou, Kroměříž, and Zlín and significant results were obtained in the Districts of Kroměřǐz (veterinary measures $p<0.01$; non-fulfilment of requirements $p<0.05$ ) and Zlín (veterinary measures $p<0.01$; non-fulfilment of requirements $p<0.05$ ). 
Table 1

Actual frequency of veterinary measures, actual frequency of non-fulfilment of the requirements for the protection of animals against maltreatment and actual frequency of inspections carried out for the monitored period in the individual districts of the monitored region, in South Moravia Region, and within the Czech Republic

\begin{tabular}{|c|c|c|c|c|c|c|c|c|c|c|c|c|}
\hline & \multicolumn{3}{|c|}{ Cattle } & \multicolumn{2}{|c|}{ Sheep and goats } & \multicolumn{3}{c|}{ Pigs } & \multicolumn{3}{c|}{ Horses } \\
\hline met. & $\begin{array}{c}\text { Non- } \\
\text { fulfil. of } \\
\text { requir. }\end{array}$ & $\begin{array}{c}\text { No. of } \\
\text { insp. }\end{array}$ & $\begin{array}{c}\text { Vet. } \\
\text { meas. }\end{array}$ & $\begin{array}{c}\text { Non- } \\
\text { fulfil. of } \\
\text { requir. }\end{array}$ & $\begin{array}{c}\text { No. of } \\
\text { insp. }\end{array}$ & $\begin{array}{c}\text { Vet. } \\
\text { meas. }\end{array}$ & $\begin{array}{c}\text { Non- } \\
\text { fulfil. of } \\
\text { requir. }\end{array}$ & $\begin{array}{c}\text { No. of } \\
\text { insp. }\end{array}$ & $\begin{array}{c}\text { Vet. } \\
\text { meas. }\end{array}$ & $\begin{array}{c}\text { Non- } \\
\text { fulfil. of } \\
\text { requir. }\end{array}$ & $\begin{array}{c}\text { No. of } \\
\text { insp. }\end{array}$ \\
\hline ČR & 521 & 262 & 20900 & 97 & 55 & 1005 & 198 & 89 & 12234 & 162 & 70 & 3646 \\
\hline JM & 64 & 29 & 2811 & 11 & 4 & 141 & 28 & 20 & 2501 & 29 & 14 & 441 \\
\hline JI & 0 & 1 & 157 & 0 & 0 & 7 & 0 & 1 & 12 & 0 & 1 & 12 \\
\hline ZR & 9 & 4 & 221 & 0 & 0 & 11 & 2 & 0 & 259 & $8 * *$ & $7 * *$ & 35 \\
\hline BK & 0 & 0 & 195 & 0 & 0 & 2 & 0 & 2 & 110 & 0 & 0 & 8 \\
\hline PV & 0 & 2 & 148 & 0 & 1 & 4 & 0 & 1 & 79 & 0 & 1 & 67 \\
\hline KR & $14 * *$ & $5 *$ & 140 & 2 & 1 & 13 & $6 * *$ & $4 * *$ & 122 & 2 & 0 & 17 \\
\hline ZL & $16 * *$ & $6 *$ & 199 & 2 & 0 & 6 & 8 & 1 & 100 & 6 & 1 & 48 \\
\hline UH & 1 & 1 & 110 & 4 & 1 & 13 & $5 *$ & $5 * *$ & 122 & 0 & 0 & 23 \\
\hline HO & 0 & 0 & 611 & 0 & 0 & 1 & 0 & 0 & 517 & 0 & 0 & 8 \\
\hline BV & 19 & 0 & 203 & 1 & 0 & 6 & 2 & 0 & 220 & 0 & 0 & 31 \\
\hline BO & 0 & 0 & 205 & 0 & 0 & 8 & 0 & 0 & 286 & 0 & 0 & 8 \\
\hline BM & 1 & 0 & 111 & 1 & 0 & 34 & 3 & 0 & 156 & 5 & 0 & 32 \\
\hline TR & 0 & 5 & 258 & 0 & 1 & 26 & 0 & 3 & 183 & 0 & 1 & 76 \\
\hline ZN & 4 & 5 & 184 & 1 & 0 & 6 & 2 & 3 & 287 & 8 & 2 & 69 \\
\hline VY & 0 & 0 & 69 & 0 & 0 & 4 & 0 & 0 & 48 & 0 & 1 & 7 \\
\hline
\end{tabular}

Explanatory notes:

Vet. meas. $=$ Veterinary measures

Non-fulfil. of requir.=Non-fulfilment of requirements

No. of insp.=No. of inspections

ČR=Czech Republic, JM=South Moravia Region, JI=Jihlava, ZR=Ždár nad Sázavou, BK=Blansko, $\mathrm{PV}=$ Prostějov, $\mathrm{KR}=$ Kroměřǐ̌, $\mathrm{ZL}=\mathrm{Zlín}, \mathrm{UH}=$ Uherské Hradiště, $\mathrm{HO}=$ Hodonín, $\mathrm{BV}=\mathrm{Břeclav}, \mathrm{BO}=\mathrm{Brno}-\mathrm{District}$, BM=Brno-City, TR=Třebíč, ZN=Znojmo, VY=Vyškov

$*, * *=$ Significantly higher values of the frequency of veterinary measures and at the same time higher values of the frequency of non-fulfilment of requirements $(p<0.05 ; p<0.01)$.

Concerning sheep and goats, the results of the actual frequency of veterinary measures and the frequency of non-fulfilment of the requirements for protection against maltreatment for the monitored period in the individual districts of the monitored region and within the Czech Republic are stated in Table 1 . Table 2 contains the relative frequency of veterinary measures and the relative frequency of non-fulfilment of the requirements for the protection of sheep and goats against cruelty for the monitored period in the individual districts of the monitored region and they are compared to the long-term values of $9.6 \%$ relative frequency of veterinary measures and $5.5 \%$ relative frequency of non-fulfilment of the requirements found within the Czech Republic as a whole. The results show that both higher (though not significant) values of the frequency of veterinary measures and higher values of the frequency of non-fulfilment of requirements were found in the District of Uherské Hradiště.

Concerning pigs, the results of the actual frequency of veterinary measures and the frequency of non-fulfilment of the requirements for protection against maltreatment for the monitored period in the individual districts of the monitored region and within the Czech Republic are given in Table 1 . Table 2 contains the relative frequency of veterinary measures and the relative frequency of non-fulfilment of the requirements for the protection of pigs 
Table 2

Relative frequency of veterinary measures and relative frequency of non-fulfilment of the requirements for the protection of animals against maltreatment for the monitored period in the individual districts of the monitored region, in South Moravia Region, and within the Czech Republic

\begin{tabular}{|c|c|c|c|c|c|c|c|c|}
\hline \multirow{2}{*}{} & \multicolumn{2}{|c|}{ Cattle } & \multicolumn{2}{c|}{ Sheep and goats } & \multicolumn{2}{c|}{ Pigs } & \multicolumn{2}{c|}{ Horses } \\
\cline { 2 - 10 } & $\begin{array}{c}\text { Veterinary } \\
\text { measures } \\
(\%)\end{array}$ & $\begin{array}{c}\text { Non-fulfilled } \\
\text { requirements } \\
(\%)\end{array}$ & $\begin{array}{c}\text { Veterinary } \\
\text { measures } \\
(\%)\end{array}$ & $\begin{array}{c}\text { Non-fulfilled } \\
\text { requirements } \\
(\%)\end{array}$ & $\begin{array}{c}\text { Veterinary } \\
\text { measures } \\
(\%)\end{array}$ & $\begin{array}{c}\text { Non-fulfilled } \\
\text { requirements } \\
(\%)\end{array}$ & $\begin{array}{c}\text { Veterinary } \\
\text { measures } \\
(\%)\end{array}$ & $\begin{array}{c}\text { Non-fulfilled } \\
\text { requirements } \\
(\%)\end{array}$ \\
\hline ČR & 2.5 & 1.3 & 9.7 & 5.5 & 1.6 & 0.7 & 4.4 & 1.9 \\
\hline JM & 2.3 & 1.1 & 7.8 & 2.8 & 1.1 & 0.8 & 6.6 & 3.2 \\
\hline JI & 0.0 & 0.6 & 0.0 & 0.0 & 0.0 & 8.3 & 0.0 & 8.3 \\
\hline ZR & 4.1 & 1.8 & 0.0 & 0.0 & 0.8 & 0.0 & $22.9 * *$ & $20.0 * *$ \\
\hline BK & 0.0 & 0.0 & 0.0 & 0.0 & 0.0 & 1.8 & 0.0 & 0.0 \\
\hline PV & 0.0 & 1.4 & 0.0 & 25.0 & 0.0 & 1.3 & 0.0 & 1.5 \\
\hline KR & $10.0 * *$ & $3.6 *$ & 15.4 & 7.7 & $4.9 * *$ & $3.3 * *$ & 11.8 & 0.0 \\
\hline ZL & $8.0 * *$ & $3.0 *$ & 33.3 & 0.0 & 8.0 & 1.0 & 12.5 & 2.1 \\
\hline UH & 0.9 & 0.9 & 30.8 & 7.7 & $4.1 *$ & $4.1 * *$ & 0.0 & 0.0 \\
\hline HO & 0.0 & 0.0 & 0.0 & 0.0 & 0.0 & 0.0 & 0.0 & 0.0 \\
\hline BV & 9.4 & 0.0 & 16.7 & 0.0 & 0.9 & 0.0 & 0.0 & 0.0 \\
\hline BO & 0.0 & 0.0 & 0.0 & 0.0 & 0.0 & 0.0 & 0.0 & 0.0 \\
\hline BM & 0.9 & 0.0 & 2.9 & 0.0 & 1.9 & 0.0 & 15.6 & 0.0 \\
\hline TR & 0.0 & 1.9 & 0.0 & 3.8 & 0.0 & 1.6 & 0.0 & 1.3 \\
\hline ZN & 2.2 & 2.7 & 16.7 & 0.0 & 0.7 & 1.0 & 11.6 & 2.9 \\
\hline VY & 0.0 & 0.0 & 0.0 & 0.0 & 0.0 & 0.0 & 0.0 & 14.3 \\
\hline
\end{tabular}

Explanatory notes:

ČR=Czech Republic, JM=South Moravia Region, JI=Jihlava, ZR=Žd'ár nad Sázavou, BK=Blansko, $\mathrm{PV}=$ Prostějov, $\mathrm{KR}=$ Kroměříž, ZL=Zlín, UH=Uherské Hradiště, HO=Hodonín, BV=Břeclav, BO=Brno-District, $\mathrm{BM}=$ Brno-City, TR=Třebíč, ZN=Znojmo, VY=Vyškov

$*, * *=$ Significantly higher values of the frequency of veterinary measures and at the same time higher values of the frequency of non-fulfilment of requirements $(p<0.05 ; p<0.01)$.

against maltreatment for the monitored period in the individual districts of the monitored region and they are compared to the long-term values of $1.6 \%$ relative frequency of veterinary measures and $0.7 \%$ relative frequency of non-fulfilment of requirements found within the Czech Republic as a whole. The results show that both higher values of the frequency of veterinary measures and higher values of the frequency of non-fulfilment of requirements were found in the Districts of Kroměřǐ̌, Zlín, and Uherské Hradiště and significant results were found in the Districts of Kroměřiž (veterinary measures $p<0.01$; non-fulfilment of requirements $p<0.01$ ) and Uherské Hradiště (veterinary measures $p<$ 0.05; non-fulfilment of requirements $p<0.01$ ).

Concerning horses, the results of the actual frequency of veterinary measures and the frequency of non-fulfilment of the requirements for protection against maltreatment for the monitored period in the individual districts of the monitored region and within the Czech Republic are stated in Table 1. Table 2 contains the relative frequency of veterinary measures and the relative frequency of non-fulfilment of the requirements for the protection of horses against maltreatment for the monitored period in the individual districts of the monitored region and they are compared to the value obtained for a long period for the $4.4 \%$ relative frequency of veterinary measures and the value of the $1.9 \%$ relative frequency of non-fulfilment of the requirements found within the Czech Republic as a whole. The results 
show that higher values of the frequency of veterinary measures and also higher values of the frequency of non-fulfilment of requirements were found in the Districts of Ždár nad Sázavou, Zlín, and Znojmo and significant results were found in the District of Ždár nad Sázavou (veterinary measures $p<0.01$; non-fulfilment of requirements $p<0.01$ ).

\section{Discussion}

The study contains comprehensive results of monitoring the protection of cattle, sheep and goats, pigs, and horses in the selected South Moravia Region in the Czech Republic for the period from 1996 to 2000. It is based on the legal standard of protection of animals specified in the legal regulations of the Czech Republic, which is very close to the legal standard of the European Union. A similar standard of fulfilment of the legal requirements for the protection of animals is expected to be required by veterinary inspectors in the Czech Republic. The study evaluates the supervisory activity according to the following scale: fulfilment of requirements, determination of veterinary measures to improve the welfare of animals (veterinary measures), and infringement of the requirements for the protection of animals against maltreatment with subsequent recourse for such maltreatment (nonfulfilment of requirements) within the South Moravia Region in the Czech Republic. No similar study for any region within Europe has been recorded in the literature available, thus the results cannot be compared to any published data. Therefore, the results found in the individual districts of South Moravia Region were compared to the long-term values of the frequency of veterinary measures and the frequency of non-fulfilment of requirements found within the Czech Republic (veterinary measures and non-fulfilment of requirements for cattle $2.5 \%, 1.3 \%$; for sheep and goats $9.7 \%, 5.5 \%$; for pigs $1.6 \%, 0.7 \%$; for horses $4.4 \%$, $1.9 \%$ ). A combination of statistically significant higher values of the frequency of veterinary measures and statistically significant higher frequencies of non-fulfilment of requirements was considered to be evidenced a worse standard of protection of animals against maltreatment in a monitored district, because the higher frequency of veterinary measures shows that the standard of protection of animals in the places of breeding and treatment needs improvement, and in case this is backed up by a higher frequency of non-fulfilment of requirements, it is evident that the shortcomings are of a serious character and are not being dealt with to the necessary extent.

The results have proven that considerably worse conditions for the protection of animals in the places of breeding and treatment were found in the Districts of Kroměřiž and Zlín for cattle, in the Districts of Kroměříž and Uherské Hradiště for pigs and in the District of Ždár nad Sázavou for horses. Breeders in these districts of the South Moravia Region do not assure sufficiently the conditions for animal protection.

\section{Úroveň ochrany hospodářských zvířat ve vybrané oblasti České republiky}

Cílem práce bylo zhodnotit úroveň ochrany skotu, ovcí a koz, prasat a koní proti týrání v jihomoravském regionu 14 okresů v České republice za období 1996 - 2000. V rámci dozorové činnosti $\mathrm{v}$ chovech zvířat a $\mathrm{v}$ místech zacházení se zvířaty byla posuzována úroveň ochrany zvířat proti týrání podle stupnice: splnění požadavků, stanovení veterinárních opatření $\mathrm{k}$ zlepšení úrovně ochrany zvířat (veterinární opatření), porušení požadavků $\mathrm{k}$ ochraně zvířat proti týrání s následným postihem za toto jednání (nesplnění požadavků). Byly zjištovány četnosti stanovení veterinárních opatření a četnosti nesplnění požadavků $\mathrm{v}$ jednotlivých okresech sledovaného regionu. Zjištěné četnosti byly porovnávány s dlouhodobě zjištěnými hodnotami pro celou Českou republiku (veterinární opatření a nesplnění požadavků pro skot $2,5 \%, 1,3 \%$; pro ovce a kozy $9,7 \%, 5,5 \%$; pro prasata $1,6 \%, 0,7 \%$; pro koně $4,4 \%, 1,9 \%$ ). Statisticky významně horší podmínky ochrany 
zviŕat $\mathrm{v}$ chovech a $\mathrm{v}$ místech zacházení se zvířaty byly zjištěny pro skot $\mathrm{v}$ okresech Kroměřiž (veterinární opatření $p<0,01$; nesplnění požadavků $p<0,05$ ) a Zlín (veterinární opatření $p<0,01$; nesplnění požadavků $p<0,05)$, pro prasata $\mathrm{v}$ okresech Kroměřǐž (veterinární opatření $p<0,01$; nesplnění požadavků $p<0,01$ ) a Uherské Hradiště (veterinární opatření $p<0,05$; nesplnění požadavků $p<0,01$ ), pro koně v okresech Ždár nad Sázavou (veterinární opatření $p<0,01$; nesplnění požadavků $p<0,01$ ). Chovatelé $\mathrm{v}$ těchto okresech jihomoravského regionu pro uvedené druhy zvířat nedostatečně zabezpečují podmínky ochrany zvířat.

\section{References}

BROOM, DM 1991a: Animal-welfare-concepts and measurement. J Anim Sci 69: 4167-4175

BROOM, DM 1991b: Assessing welfare and suffering. Behav Process 25: 117-123

BROOM, DM 1996: How well do farm animals cope with their environment during transport? Fleischwirtschaft 76: $279-281$

BROOM, DM, CORKE, MJ 2002: Effects of disease on farm animal welfare. Acta Vet Brno 71:133-136

HORVATH, G, VISNYEI, L 2000: Protection of animals during transport in Hungary. Deut Tierarztl Woch 107: 43

HORVATH, G, VISNYEI, L 2001: Questionnaire assessment of the welfare of pigs. Acta Vet Hung 49: 1-10

MEYER, $\mathrm{H}$ 2000: The rational reason in the German law of animal welfare, regarding the breed and the use of horses. Pferdeheilkunde 16: 229-242

RUIZ-DE-LA-TORRE, JL, VELARDE, A, DIESTRE, A, GISPERT, M, HALL，SJG，BROOM，DM, MANTECA, X 2001: Effects of vehicle movements during transport on the stress responses and meat quality of sheep. Vet Rec 148: 227-229

RUSHEN, J 1996: Using aversion learning techniques to asssess the mental state, suffering and welfare of farm animals J Anim Sci 74: 1990-1995

SAMBRAUS, HH 1992: The prevention of cruelty to animals, natural-science and ethology. Arch Tierz 35: 181192

SAMBRAUS, HH 1997: Animal behaviour - An indicator for species specific animal husbandry. Arch Tierz 40: 26-34

STEINHARDT, M, THIELSCHER, HH 1998: Daily performed transport stress and adaptation of calves to shorthaul road transport. Effects of rearing conditions on hormonal, metabolic and hematological variables and individual reaction patterns. Landbauforsch. Volk 48: 65-77

VON BORELL, E 1999: Animal welfare as a production factor? Zuchtungskunde 71: 473-481 